\title{
SUMMARY
}

Voronina Hanna, Gutsan Lesya. Problems of Careers Education and Guidance of High School Students: English Experience and Ukrainian Realities.

The article is devoted to the urgent issues of adolescents' preparation to the challenges of modern employment. It represents the comparative analysis of careers education and guidance in England and Ukraine and discusses the theoretical issues and practical approaches to career counselling for high school students. The methods used in the study are comparative analysis of scholarly resources on research problems, generalization and conclusion of information obtained.

Based on the analysis of legislative documents and current studies it has been concluded that the problems of careers education and guidance are of great interest among both English and Ukrainian educationalists. The latest innovations in work-related learning for future specialists and current recommendations of the Department for Education for career service provision in English schools are focused on. Numerous opportunities for English high school students to gain working experience are highlighted and statutory requirements for personal and professional development in modern learning environment are described. English experience of successful careers offer for young Londoners illustrates relevant governmental support and focus on the first stages of adolescents' career design.

Today, Ukrainian educators emphasize on the importance of transition from oldfashioned passive teaching to active learning. They state that the task of modern school is to educate young generation capable of self-learning and self-improvement. However, few modern schools in Ukraine can offer students a strategy for career planning and professional development or provide opportunities for acquiring hard and soft skills. Since New Ukrainian school states the priority of high school reformation, it definitely needs active steps in modernization of careers education and guidance for future specialists. Ukrainian scholars suggest their vision of the researched issue through the complex of career design syllabuses for high school students and career teachers.

Further research of this issue may result in successful transformation of careers education and guidance in Ukraine which will help high school students build a successful career in future.

Key words: careers education and guidance, high school students, England, workrelated learning, career design, Ukrainian schools.

удк 34:364.69-053.5

Анна Докаленко

Сумський державний педагогічний

університет імені А. С. Макаренка

ORCID ID 0000-0001-9581-0118

DOI 10.24139/2312-5993/2019.05/035-046

\section{ОСОБЛИВОСТІ ОРГАНІЗАЦІЇ ОЗДОРОВЛЕННЯ ТА ВІДПОЧИНКУ ДІТЕЙ: ЗАКОРДОННИЙ ДОСВІД}

Метою статmі є аналіз організації оздоровлення та відпочинку дітей за кордоном. Методи дослідження: аналіз і синтез науково-методичної літератури. У статті проаналізовано зарубіжний досвід організації дитячого оздоровлення та відпочинку. Досліджено особливості його організачії в країнах далекого та близького зарубіжж. Сучасні закордонні табори розглядаються як важлива складова системи 
безперервної освіти, де дитина може не лише покращити своє здоров'я, але й збагатити свої знання. Визначено можливості впровадження зарубіжного досвіду оздоровлення та відпочинку дітей у вітчизняну практику.

Ключові слова: оздоровлення та відпочинок дітей, табір, координація та взаємодія, туризм, система дитячого оздоровлення, виховання та освіти, рекреація.

Постановка проблеми. Сьогодні питання зростання здорової нації стоїть особливо гостро, адже погана екологія, недостатній рівень економічної забезпеченості, зменшення рухової активності, зумовлене великим навчальним навантаженням, упровадження комп'ютерних технологій у повсякденний побут негативно впливають на стан здоров'я дітей та підлітків. Переважна більшість із них в Україні мають відхилення в стані здоров'я, близько половини - незадовільну фізичну підготовленість. Наявна система охорони здоров'я не може зупинити процес хронічних захворювань. Сталість несприятливих тенденцій у стані здоров'я підростаючого покоління вимагає нових рішень щодо організації оздоровлення та відпочинку дітей.

Слід зазначити, що провідні держави світу визначили для себе пріоритетні завдання щодо проблематики оздоровлення та відпочинку дітей. Ідеї зміцнення здоров'я розглядаються в єдності і становлять основу концепції літнього відпочинку. Європейські стандарти і підходи до забезпечення оздоровлення дітей викладені в «Конвенція ООН про права дитини» та основні напрями яких визначено Стратегією Ради Європи з прав дитини (2016-2021). Рекреаційна сфера на Заході набуває шалених обертів, набираючи різноманітних форм як одна з головних сфер суспільного життя. Різноманітні рекреаційні програми та заходи спрямовані на підвищення фізичного рівня та психоемоційного стану дитини.

Дослідження організації літнього відпочинку дітей за кордоном маловідомі. Тим часом, досвід роботи закордонних таборів міг би мати величезне значення для організації літнього відпочинку в Україні.

Аналіз актуальних досліджень. Проблемні питання організації дитячого відпочинку та оздоровлення є предметом розгляду багатьох науковців. Зокрема, В. М. Горбинко та С.І.Вагнер відпрацьовують технологію досліджень в області оздоровчого відпочинку дітей і підлітків, ураховують педагогічний досвід західних країн в області дозвілля дітей та підлітків. У статті «Світова історія масових «дитячих таборів»» В. М. Горбинко дослідила історію виникнення та розвиток організаційних форм оздоровчої роботи з дітьми в Америці та Західній Європі починаючи з середини XIX століття. Вони вперше у вітчизняній теорії дослідили підходи, технології та наявний в Україні досвід за диференційованими напрямами. Зазначену проблему досліджували Б. Лихачов, Б. Ломов (вільний час дітей та його організація), А. А. Бесєдіна, В. З. Васильєв (фіз- 
культура та спорт), С. Коновець, М. Ф. Дік (нормативно-правове забезпечення табору з денним перебуванням). Питанням розвитку соціального туризму присвячені роботи М.В.Биржакова, М. А. Морозова. Щодо монографічного дослідження М. О. Наказного, то воно присвячене розробці концептуальних підходів до проектування діяльності дитячого оздоровчого закладу та визначенню умов його впровадження (Наказний, 2010). При всій специфічності різних сучасних тенденцій у них відображені актуальні і глобальні підходи до управління, змісту, форм і методів вирішення означеної проблеми.

Учені відпрацьовують технологію досліджень в області оздоровлення дітей, ураховують педагогічний досвід західних країн в області дозвілля дітей. Здійснений аналіз вітчизняних та зарубіжних матеріалів свідчить про зацікавленість даним питанням науковцями різних галузей. Проте, вивчення закордонного досвіду та можливостей його імплементації у вітчизняну практику - вкрай недостатньо.

Метою статті $€$ аналіз організації оздоровлення та відпочинку дітей за кордоном.

Методи дослідження: аналіз і синтез науково-методичної літератури.

Виклад основного матеріалу. Рекреаційно-оздоровча діяльність у європейських і північноамериканських країнах досить багатопланова. Тут створені профільні цілорічні або літні табори, програми яких орієнтовані на спортивне вдосконалення вихованців, формування в них лідерських якостей, активний відпочинок, творчу самореалізацію. Оздоровчі програми таборів припускають ретельний моніторинг стану здоров'я, навчання основам здоров'я, забезпечення безпеки в поєднанні з духовно-моральним удосконаленням, спортивними іграми і змаганнями, доповнюваними технологіями іпотерапії та арт-терапії. Методологічним підґрунтям літнього оздоровлення та відпочинку дітей і підлітків за кордоном є взаємозбагачення ідеями різних філософських концепцій і постійне накопичення досвіду з питань літнього оздоровлення, що, у цілому, формує уявлення про систему соціальних стосунків між людьми та дружніх відносин між народами (Jensen, 1979).

Крім того, набуває поширення і така форма дитячого відпочинку та оздоровлення, як спортивно-оздоровчий туризм - одна 3 найбільш ефективних оздоровчих технологій, які сприяють формуванню здорового способу життя людини й суспільства в цілому. Адже є важливим способом передачі новому поколінню накопиченого людством життєвого досвіду і матеріально-культурної спадщини, формування ціннісних орієнтацій, морального оздоровлення та культурного розвитку нації. Тобто, по-суті, $\epsilon$ одним із шляхів соціалізації особистості. 
3 урахуванням зібраного й вивченого матеріалу ми спробували розглянути діяльність західних рекреаційних центрів у таких напрямах: рекреаційна; релігійна; діяльнісно-екологічна; експериментальна освіта.

Рекреаційна діяльність у роботах учених розглядається через розваги й дозвілля. Спочатку дозвілля на Заході асоціювалося з поняттям «гра», що включає широкий спектр діяльності (заняття спортом, мистецтвом, ремеслом), виступаючи особливим у плані задоволення дозвіллєвих потреб, відновлення психологічного балансу (Carlson, 1925).

Згодом структура рекреаційної діяльності дітей привертає увагу відомих фахівців в області соціології. Так, наприклад, Дж. Б. Неш розглядає творчу діяльність як одну з головних, що вінчають такі блоки: активну діяльність; емоційну розрядку; розваги і проведення часу (Butler, 1967).

Сфера рекреації звертає на себе увагу Дж. Фітцджеральда. Значимість рекреаційної діяльності в години дозвілля він бачить у «возвишенні і схваленні» з боку оточуючих. Така позиція підкреслюється багатьма дослідниками, у яких конструктивність і цінність рекреації розглядається як для окремого індивіда, так і для суспільства в цілому (Jensen, 1979).

Наявність рекреаційних видів діяльності, зазначає О. П. Торговкіна, характеризує суспільство як економічно розвинене. Автор у своїй роботі поділяє вільний час на «дозвіллєву» та "рекреаційну» діяльність. У першому випадку акцент робиться на тій частині часу, яку характеризує відпочинок, в останньому акцент переноситься на діяльність у межах вільного часу (Торговкина, 1999).

«Рекреаційний вибух» у розвинених країнах передбачає використання водних, земельних і матеріально-технічних організаційних засобів із урахуванням особистих і суспільних потреб для організації літнього оздоровчого відпочинку (Carlson, 1925).

Указуючи на гармонійний розвиток особистості, А. Камінський передбачає поєднання дозвіллєвих функцій і власного інтелектуального, соціального, художнього, технічного і фізичного розвитку (Jensen, 1979).

У сукупності з традиційними рекреаційними організаціями державного і приватного типу виникає необхідність доповнення сформованої структури. Під впливом історичних, соціально-педагогічних чинників розвитку індивідуальних і суспільних потреб заміські табори набувають особливої цінності для виховання дітей. Вивченням історії цього руху займаються різні дослідники, серед них Е. Уілс, яка виділяє чотири етапи їх становлення:

Розглядаючи перший етап 1861-1910 рр. табірного руху, слід виділити деякі особливості: 
- диференційований підхід;

- діяльність приватних таборів;

- організація першого табору для дітей-інвалідів.

Літні табори, представлені церковними інститутами, починають функціонувати ще на початку XIX ст. Перший організований табір з'явився в Північній Америці в 1840 р. Організація дозвілля велася за трьома напрямами:

1) пропаганда релігійних аспектів;

2) рекреаційна діяльність;

3) соціальна діяльність

Об'єднуючим аспектом виділених напрямів $€$ діяльність християнських таборів, у якій присутні ідеологічні, економічні мотиви. Широка програма цих організацій ставить перед собою такі цілі: розвиток навичок у домашніх справах; вивчення аспектів педагогіки; виховання здорового способу житя; життя на відкритому повітрі. Церква стає тим соціальним інститутом, який займає велике місце в структурі вільного часу підростаючого покоління. Зокрема, у релігійному таборі США діти пізнають релігійні цінності, беручи участь у відповідних заходах (молитви, заняття тощо), адже такі табори засновані на біблейських принципах (Jensen, 1979). Слід зазначити, що діяльність усіх літніх дитячих таборів має свої особливості: вони мають термін відпочинку від 1 до 8 тижнів та гендерні розмежування (у них можуть відпочивати або тільки дівчатка, або тільки хлопці).

Продовжуючи розгляд першого етапу, слід зазначити, що в цей період відбувається зародження скаутського руху в 1907 р. в Англії, у 1910 р. («Бойскаути») і в 1912 р («Герлскаути») - в Америці. Однією з форм роботи Всесвітньої Асоціації скаутів $\epsilon$ організація міжнародних літніх таборів (Новые ценности образования, 1998). Різноманітна за формами й методами робота скаутської організації сприяє розвиткові дитячої ініціативи, навичок і вмінь здорового способу житя, гармонійного фізичного розвитку. Організаційні та змістові засади діяльності скаутів у літніх таборах відображено у табл. 1.

Скаутські організації існують роздільно для хлопчиків і дівчаток, але принципи їх діяльності однакові. Скаути за кордоном беруть на себе той аспект соціалізації, який пов'язаний із підготовкою переконаних і активних захисників своєї держави. Закони скаутів висловлюють загальногуманістичні норми поведінки, виховують патріотизм (Cross Country University Running Camp). 
Таблиця 1

Організаційні та змістові засади діяльності скаутів у літніх таборах

\begin{tabular}{|l|l|l|l|}
\hline Напрями діяльності & \multicolumn{1}{|c|}{ Вік дітей } & \multicolumn{1}{|c|}{ Джерела підтримки } & \multicolumn{1}{|c|}{ Фінансування } \\
\hline - заняття спортом; & $-8-11$ років - & - уряд; & - членські внески; \\
- вивчення & початківці; & - церква; & - пожертвування \\
природи; & $-11-17$ років - & - філантропічні & фондів, приватних \\
- воєнізовані ігри; & розвідники; & організації; \\
- підготовка скаут- & $-17-18$ років - & - приватний капітал & \\
майстрів; & «розбійники», & & \\
- організація & «бродяги» & & \\
міжнародних літніх & & & \\
таборів & & & \\
\hline
\end{tabular}

Витоки табірного руху в США пов'язані з діяльністю Американської асоціації таборів (ААТ). ААТ - це приватна некомерційна освітня організація, членами якої $\epsilon$ директори таборів, адміністративні працівники, офісні працівники, бізнесмени, студенти, пенсіонери, волонтери та інші особи, пов'язані з організацією і проведенням відпочинку й оздоровлення дітей. ААТ - єдина організація, яка проводить акредитацію таборів усіх типів, займається освітніми програмами, видає свій журнал на допомогу таборам, книги для працівників таборів, співпрацює з ученими, бізнесменами, пропагує і вирішує актуальні питання на урядовому рівні (Camp Eden).

На другому етапі 1910-1918 рр. відзначають зростання табірного руху в межах створення нових асоціацій і рухів. У 1912 р. у США виникає професійна Асоціація директорів таборів для хлопчиків, а в 1916 р. створюється подібна Асоціація для дівчаток. Р. Карлсон пояснює розвиток табірного руху в розглянутий нами період «запитами й потребами молодих людей того часу», які визначаються низкою критеріїв: організований побут, відсутність тиску урбанізації, знайомство з сільським побутом, близькість до природи, розширення кола знайомств, знайомство з іншою культурою, тимчасова незалежність, елементи пригод (Camp Eden).

Виділені критерії характеризують такі типи таборів: літній табір із житлом; цілодобовий літній табір у межах діяльності сільського клубу; денний табір при фермі, школі, парку, терміном на один день; спортивний табір; шкільний табір; приватний табір; міжнародний табір. Оздоровча спрямованість дитячих заміських таборів гармонійно поєднується з елементами навчально-виховної діяльності, сприяє зміцненню не лише фізичного стану дітей, але і їх духовно-етичному розвитку, додає роботі заміських таборів системного й ціліснішого характеру, підвищує ії педагогічний потенціал (Страна, 2014). 
У педагогічних програмах американських таборів ураховуються всі сучасні потреби дітей. Традиційно в таборах проводяться різноманітні заходи на природі: походи, плавання, спортивні та рухливі ігри, природоохоронними, екологічними справами. Найбільш поширені види діяльності: навчання скелелазінню, походи, катання на гірських велосипедах, сноубордінг. Великою популярністю в дітей користуються водні види спорту (Camp Eden).

Характеризуючи третій етап 1918-1945 рр. слід виділити організацію клубів з проблем тваринництва для учнів середніх шкіл в Австралії (1928 р), Шотландії (1937), поділяючи їх на сільський, шкільний, міський. Визначальним фактором $є$ диференційований підхід. Розширюючи можливості дозвіллєвих організацій, на підставі виданого в 1925 р. посібника з курсу гри, у закладах освіти вводяться предмети, пов'язані $з$ організацією дозвілля. Слід зазначити, що широко поширені пригодницькі програми з різноманітними спортивними заходами, елементи квесту, де необхідним $€$ поєднання розумових і фізичних навичок для досягнення певної мети. Всі вони спрямовані на взаємодію основних елементів рекреації: у цікавій ігровій формі разом із колективом діти використовують фізичні дані та розумові навички (аналізуючи інформацію).

Четвертий етап «Період визнання» (з 1945 р. по теперешній час) вже в повному обсязі виходить на міжнародну співпрацю, стираючи відмінності між таборами різних країн і виробляючи універсальні педагогічні методи і принципи формування дозвілля для дітей.

Відзначаючи динаміку зростання західних таборів, більшість дослідників (Дж. В. Сміт, Х. Димок) указують у якості основних причин зростання міст, розвиток механізації. Останнє стало поштовхом до співпраці міських освітніх центрів із заміськими таборами. Сьогодні табір у США - це важлива складова системи безперервної освіти, де дитина може укріпити своє здоров'я, збагатити свої знання, зрозуміти принципи життя групи, використовувати різнопланові ситуації для самовираження та самореалізації (Из истории лагерного движения в США).

Сучасні дослідження даної проблеми позначають екологічне спрямування як діяльну (практико-орієнтовну) екологічну освіту в таборі ДЕО. Концепція ДЕО в країнах Західної Європи, Азії та Америки була викликана інформаційним вибухом 1950-1960-х рр., кризою системи освіти, що призвело до становлення «сфери експериментального освіти» ("experiental education" - “ехperience” - життєвий досвід). У даний час ДЕО, включене в діяльність заміського табору, передбачає: 
- пізнання світу шляхом придбання особистого досвіду в процесі знайомства з цінностями національної культури;

- подолання труднощів (шляхом прийняття самостійних рішень);

- мотивацію дій, учинків;

- осмислення своєї ролі й місця в суспільстві, визначення своїх потреб;

- становлення світоглядних функцій;

- розвиток індивідуальності, працездатності, волі в досягненні мети;

- динаміку особистості, внутрішньої свободи.

Методи і принципи експериментальної освіти використовуються в навчальних програмах шкіл, літніх таборів, клубів, у роботі реабілітаційних центрів. Спеціально розроблені програми в цьому напрямі враховують прагнення підростаючого покоління до небезпек і пригод, стимулюють до прийняття відповідальних рішень, виробляють навички взаємопідтримки й розуміння. Застосування в західній практиці експериментальної освіти служить формуванню характеру дітей, вихованню в них громадянської і моральної відповідальності, сприяє набуттю власного досвіду. У 1977 р. створюється Асоціація експериментальної Освіти. У неї входять США, Японія, Лесото, Зімбабве. Включаючи всі соціальні та вікові верстви населення, експериментальна освіта в повсякденному житті реалізується через рух Аутвордбаунд і розвивається за трьома напрямами:

1) програми, спрямовані на розвиток професійних навичок;

2) програми соціального розвитку та розвитку особистості;

3) терапевтичні програми.

У даний час всі напрями чітко простежуються в державних, приватних школах, літніх таборах, співпраця яких пропонує більш широкий спектр діяльного освіти - літні практики, експедиції, мережа безкоштовних спортивних, туристичних шкіл, секцій, станцій юних техніків.

Крім того, набуває поширення й така форма дитячого відпочинку і оздоровлення, як спортивно-оздоровчий туризм - одна з найбільш ефективних оздоровчих технологій, які сприяють формуванню здорового способу життя людини і суспільства в цілому.

Аналіз програм таборів різних західних країн дозволяє нам виділити такі педагогічні складові:

- самостійність. У процесі табірної зміни в дитини виробляється почуття впевненості в своїх діях і вчинках;

- взаємодія в групі - отримання подібного досвіду забезпечує взаєморозуміння по відношенню до інших;

- набуття вмінь; 
- реалізацію набутих умінь у повсякденному житті;

- реалізація своїх здібностей на практиці;

- «прийняття цінностей один одного» - відмінність соціальних систем (мова, культура, звичаї) в таборі набуває особливої значущості, слід формувати позитивну позицію по відношенню до цінностей іншої країни.

Таким чином, із розвитком табірного руху за кордоном відбувається переосмислення функцій оздоровчого табору для дітей. Розширення мережі таборів робить акцент на виховання в підростаючого покоління екологічної свідомості. Закордонна практика свідчить про те, що зміст оздоровлення та відпочинку спрямований головним чином на розвиток особисті дитини, а саме: фізичних та творчих здібностей, культурних цінностей, що супроводжуються широким спектром форм, методів та прийомів.

Що стосується країн ближнього зарубіжжя, то Узбекистан входить у десятку країн світу, де краще всього турбуються про здоров'я дітей. Отже, 92 \% дітей у країні за параметрами свого розвитку відповідають стандартам Всесвітньої організації охорони здоров'я (Страна, где все делается во имя детей, во имя будущого). Пріоритетом державної політики стало виховання гармонійно розвинутого, фізично здорового та духовно зрілого підростаючого покоління. Вдвічі збільшено кількість спеціалізованих профільних таборів (інтелектуального розвитку, соціальної адаптації, військовоспортивно-оздоровчих, еколого-біологічних, художньої та технічної творчості.

Казахстан є однією з пострадянських країн, що має значний досвід організації літнього відпочинку дітей, в основу якого закладено два пріоритети - виховання та оздоровлення. Принципами державної підтримки дитячого оздоровлення та відпочинку є:

-рівних можливостей, що передбачає надання соціальних гарантій всім категоріям дітей;

-пільговості - забезпечення всіх видів державної допомоги у фінансовому вираженні;

-безперервного аналізу та контролю всіх гілок влади щодо недопущення расизму, насилля та екстремізму, релігійних суперечок при плануванні програм, забезпечення комфортабельного відпочинку дітей і підлітків;

-залучення дитячих центрів до участі, на правах партнерів, у реалізації республіканських, обласних, районних, міських програм щодо захисту прав дітей (Стратегчческий план развития Республики Казахстан до 2020 года).

Особливостями організації оздоровлення та відпочинку дітей у країнах ближнього зарубіжжя є надання великої уваги фізичній культурі та 
спорту, військово-патріотичному вихованню, створенню організованих форм роботи з дітьми на базі існуючих будинків творчості, дитячоюнацьких спортивних шкіл, підліткових клубів, сільських будинків культури, охопленню різними формами відпочинку та оздоровлення дітей із асоціальних сімей, зайнятості підлітків, в т.ч. маловитратними формами відпочинку (трьох-п'ятиденними походами, екскурсіями).

Висновки та перспективи подальших наукових розвідок. Таким чином, функціонують різні типи таборів, з різною тривалістю змін, різними джерелами фінансування, різної форми власності та 3 різними педагогічними програмами. Сьогодні літні дитячі табори - це важлива складова системи безперервної освіти, що надає оптимальні можливості особистості у сфері оздоровлення та відпочинку.

Ми дійшли висновку, що закордонний досвід $є$ яскравим прикладом того, як можна якісно реформувати процес оздоровлення й відпочинку дітей у нашій державі. Його аналіз, осмислення та належна оцінка сприятимуть розвиткові різнопланових підходів до вирішення проблем у галузі літнього оздоровлення та відпочинку дітей в Україні. Відтак, закордонний досвід організації оздоровлення та відпочинку дітей потребує подальших наукових досліджень із метою забезпечення реалізації права дітей на повноцінне та якісне оздоровлення.

\section{ЛІТЕРАТУРА}

Butler, G. J. (1967). Introduction to Community Recreation. N. Y.

Camp Eden. Retrieved from: http://www.campeden.org/

Carlson, R. (1925). The values of Camping American Camping Association. Martinsville.

Cross Country University Running Camp (XCU). Retrieved from: http://xcucamp.com

Jensen, C. R. (1979). Outdoor Recreation in America Trends, Problems and Opportunities. Minneaplis.

Из истории лагерного движения в США. Режим доступу: studopedia.org/ 6-56222.html.

(From the history of the camp movement in the United States. Retrieved from: studopedia.org/ 6-56222.html.).

Наказний, М. О. (2010). Проектування діяльності дитячого оздоровчого закладу: теорія і технологія. Дніпропетровськ (Nakaznyi, М. О. (2010). Designing activities of the children's health institution: theory and technology. Dnipropetrovsk).

Новые ценности образования: философия и педагогика каникул (1998). М. (New values of education: philosophy and pedagogy of vacations (1998). М.).

Страна, где все делается во имя детей, во имя будущего (2014). Режим доступа: http://uzbekistan.org.ua/ru/aktualno/year_2014/3490. (The country where everything is done in the name of children for the future (2014). Retrieved from: http://uzbekistan.org.ua/en/aktualno/vear 2014/3490).

Стратегический план развития Республики Казахстан до 2020 года. Утвержден Указом Президента Республики Казахстан от 1 февраля 2010 года № 922. Режим 
доступа: http://ru.government.kz/docs/u100000922 20100201.htm (Strategic plan of development of the Republic of Kazakhstan till 2020. Approved by Decree of the President of the Republic of Kazakhstan dated February 1, 2010 No. 922. Access mode: http://ru.government.kz/docs/u100000922 20100201.htm).

Торговкина, О.П. (1999). Теоретические основы и опыт решения педагогических проблем в детских загородных лагерях США (автореф. дисс. ... канд. пед. наук: 13.00.01). М. (Torhovkina, O. P. (1999). Theoretical bases and experience of solving pedagogical problems in children's country camps in the USA (PhD thesis abstract). M.).

\section{PEЗЮME}

Докаленко Анна. Особенности организации оздоровления и отдыха детей: зарубежный опыт.

Целью статьи является анализ организации оздоровления и отдыха детей за рубежом. Методы исследования: анализ и синтез научно-методической литературы и электронных ресурсов. В статье проанализирован зарубежный опыт организации детского оздоровления и отдыха. Исследованы особенности его организации в странах дальнего и ближнего зарубежья. Современный зарубежный лагерь рассматривается как важная составляющая системы непрерывного образования, где ребенок может не только укрепить свое здоровье, но и обогатить свои знания. Определены возможности внедрения зарубежного опыта оздоровления и отдыха детей в отечественную практику.

Ключевые слова: оздоровление, отдых, лагерь, координация $u$ взаимодействие, туризм, система детского оздоровления, воспитания и образования, рекреация.

\section{SUMMARY}

Dokalenko Anna. Peculiarities of children's recreation and rest organization: foreign experience.

The aim of the article is to analyze organization of children's recreation and rest abroad. Methods of research: analysis and synthesis of scientific-methodological literature. The article analyzes foreign experience of organization of children's recreation and rest. The peculiarities of their organization in the foreign countries are studied. Recreation and health activities in the European and North American countries are quite diversed. Modern camps abroad are considered an important component of the system of continuous education, where the child cannot only strengthen his health, but also enrich his knowledge. The recreational orientation of children's camps is harmoniously combined with the educational and upbringing activities, promotes strengthening not only of the physical condition of children, but also of their spiritual-ethic development, makes the work of suburban camps more systematic and holistic, increases its pedagogical potential. The pedagogical programs of American camps take into account all the modern needs of children.

With the development of the camp movement abroad, there is a rethinking of the functions of the recreation camp for children. Expansion of the camp network emphasizes upbringing in the younger generation of ecological consciousness. Foreign practice shows that the content of recreation and rest is directed mainly at development of a child's personality, namely: physical and creative abilities, cultural values, accompanied by a wide range of forms, methods and techniques. 
Thus, there are different types of camps, of various duration, different sources of financing, different forms of ownership and different pedagogical programs. Today, summer children's camps are an important part of the system of continuous education, give the person the best opportunities in the field of recreation and rest.

It is concluded that foreign experience is a vivid example of how it is possible to qualitatively reform the process of health improvement and recreation of children in our country. Its analysis, reflection and proper assessment will promote development of diverse approaches to solving the problems of summer recreation and rest of children in Ukraine. Therefore, the foreign experience of organizing children's health and recreation needs further research in order to ensure realization of the children's right to full and qualitative improvement.

Key words: health improvement, rest, camp, coordination and interaction, tourism, child health improvement, upbringing and education, recreation.

УдК 372.2(73+71)

Олена Огієнко

Сумський державний педагогічний

університет імені А. С. Макаренка

ORCID ID 0000-0002-3089-6288

DOI 10.24139/2312-5993/2019.05/046-057

\section{ОСВІТА КОРІННИХ НАРОДІВ У США І КАНАДІ: ICTOРІЯ I СУЧАСНI РЕАЛIÏ}

Визначено історичні, соціально-економічні, політичні детермінанти становлення та розвитку освіти корінного населення у США і Канаді; показано взаємозв'язок особливостей функціонування системи освіти корінного населення $з$ процесами колонізації північноамериканських земель європейцями; розкрито сутність політики асиміляції корінного населення, яка породжувала расову дискримінацію корінного населення країн, посилювала ї маргіналізацію і деградацію; закцентовано увагу на діяльності шкіл-інтернатів для дітей корінних народів як однієї з форм освітньої асиміляції, показано їх негативний вплив на виховання дітей корінних народів; виявлено, що сучасною тенденцією освітньої політики щодо корінних народів $є$ перехід від політики асимілячії до політики інтеграції; показано, що сучасна освіта корінних народів у США і Канаді базується на принципах мультикультуралізму, демократії, гуманізму, на начіоналістичному підході, урахуванні освітніх потреб та потреб ринку праці.

Ключові слова: корінні народи, освіта корінних народів, законодавство, иколиінтернати для дітей корінних народів, освітня політика асиміляції, освітня політика інтеграції, США, Канада.

Постановка проблеми. У сучасному глобалізованому світі, в умовах активізації інтеграційних та міграційних процесів, розвитку мультикультурного суспільства важливого значення набуває проблема освіти корінного населення країн. У підсумковому документі Генеральної Асамблеї «Всесвітня конференція по корінним народам» (2014) зазначалося, що необхідно забез- 